\title{
Representation of Communicative and Pragmatic Frame 'Intellect' In English, German and Russian Paremiological World Pictures
}

\section{Representación del marco comunicativo y pragmático "intelecto" en imágenes del mundo paremiológico en inglés, alemán y ruso}

\section{Shaimardanova Milyausha R}

Kazan Federal University, Ph.D, Professor Assistant, Department of English Philology and Crosscultural Communication, Faculty of Foreign Languages, Elabuga Institute

ORCID: 0000-0002-4952-4513

\section{Zorina Anna V}

Kazan Federal University, Ph.D, Professor Assistant, Department of European Languages and Cultures, Higher School of Foreign Languages and Translation Studies, Institute of International Relations

ORCID: 0000-0002-9642-3803

Akhmetova Leysan A

Kazan Federal University, Ph.D, Professor Assistant, Department of English Philology and Crosscultural Communication, Faculty of Foreign Languages, Elabuga Institute

ORCID: 0000-0002-7092-5012

Received 09-08-20 Revised 10-10-20 Accepted 20-12-21 On line 03-01-21

* Correspondence

Email: milyausha33@mail.ru

\section{Citation:}

Shaimardanova Milyausha R., Zorina Anna V., Akhmetova Leysan A (2020). Representation of Communicative and Pragmatic Frame 'Intellect' In English, German and Russian Paremiological World Pictures. Propósitos y Representaciones, 9(SPE2), e1049. http://dx.doi.org/10.20511/pyr2021.v9nSPE2.1049 


\begin{abstract}
The purpose of the study is to conduct a cognitively-comparative analysis of the representation of the communicative-pragmatic frame intellect (Russian $y_{M}$, German Klugheit) objectified in proverbs of English and Russian languages, which, being a reflection of the world view of a particular ethnic group, are a conventional way of expressing stereotypes of the people. The scientific novelty of the study lies in a comprehensive analysis of stereotypical assessments of the intellectual abilities of an individual as a representative of a particular society, through the study of paremias containing the nomination of the intellect - foolishness binome in the English, German and Russian paremiological view of the world. The article bears the result of the study of 1243 proverbial units - 412 English, 433 German and 398 Russian proverbs and sayings. As a result, universal and unique stereotypical representations of the value and the availability of knowledge and intelligence were revealed; the relationship between the level of mental abilities and behavior, luck; dependence of intelligence on alcohol, age, wealth and happiness. In addition, a correlation was determined between related (English and German) and unrelated (Russian) languages, which, in turn, facilitates the process of cognitive learning of the languages studied. Consequently, the article contributes to solving the problems of intercultural communication.
\end{abstract}

Key words: communicative and pragmatic frame, paremiological units, paremiological world picture, mental abilities, proverbial stereotypes.

\title{
Resumen
}

El propósito del estudio es realizar un análisis cognitivo-comparativo de la representación del intelecto marco comunicativo-pragmático (ruso yм, alemán Klugheit) objetivado en refranes de los idiomas inglés y ruso, que, al ser un reflejo de la cosmovisión de un grupo étnico particular, son una forma convencional de expresar los estereotipos de las personas. La novedad científica del estudio radica en un análisis exhaustivo de las valoraciones estereotipadas de las capacidades intelectuales de un individuo como representante de una sociedad particular, a través del estudio de las paremias que contienen la nominación del intelecto - binome de locura en inglés, alemán y ruso. visión paremiológica del mundo. El artículo es el resultado del estudio de 1243 unidades proverbiales: 412 refranes y dichos en inglés, 433 en alemán y 398 en ruso. Como resultado, se revelaron representaciones estereotipadas universales y únicas del valor y la disponibilidad del conocimiento y la inteligencia; la relación entre el nivel de habilidades mentales y comportamiento, suerte; dependencia de la inteligencia del alcohol, la edad, la riqueza y la felicidad. Además, se determinó una correlación entre idiomas relacionados (inglés y alemán) y no relacionados (ruso), lo que, a su vez, facilita el proceso de aprendizaje cognitivo de los idiomas estudiados. En consecuencia, el artículo contribuye a resolver los problemas de la comunicación intercultural.

Palabras clave: marco comunicativo y pragmático, unidades paremiológicas, imagen paremiológica del mundo, habilidades mentales, estereotipos proverbiales.

\section{Introduction}

The relevance of the research topic is due to the increased interest in comparative paremiology from the position of linguistic culturology, the increased attention of researchers to the problems of intercultural communication. 'Linguistic culturology, exploring the national cultural specificity of peoples, the ethnic mentality of a particular language community, the attitude of native speakers of a particular language to particular fragments of the world, the embodiment of the national mentality in the language; promotes mutual understanding and respect in the process of intercultural communication' (Zangieva, 2014: 115).

Enhancing the relevance and comparative nature of the study. The identification of national specific features of the methods of categorizing and conceptualizing linguistic reality in the process of comparing three distantly related languages helps to identify the ethnic originality of 
the linguistic picture of the world, both general and specific cultural features that are different for each language.

To achieve this research goal, the following tasks must be solved:

- to substantiate the appropriateness of applying the frame analysis of the binary opposition intellect - foolishness / Klugheit - Dummheit / yм - zлуnость in proverbs and sayings of the Russian, English and German languages;

- to identify in the paremiological fund of English, German and Russian languages the corpus of paremias containing the nomination binomial intellect-stupidity;

- to describe the characteristic features of the frame structure of the conceptual opposition intellect - foolishness / Klugheit - Dummheit / yм - глуnость in English, German and Russian paremiological pictures of the world;

- to identify universal and unique stereotypical assessments of the intellectual abilities of representatives of the English, German and Russian peoples, represented in the paremiological units of the ethnic groups under consideration.

The study material was made up of English, German and Russian proverbs, sayings, taken out by the method of special sampling from the following paremiological collections: Bryan G. B \& Mieder W. (2005) 'The Dictionary of Anglo-American Proverbs and Proverbial Phrases', Bertram A. (2003) 'NTC's Dictionary of Proverbs and Cliches', Mieder W. (2008) 'English Proverbs', Simrock K. 'Deutsche Sprichwörter', Beyer H. \& Beyer A. (1987) 'Sprichwörterlexicon', Anikin V. P. (1988) 'Russian Proverbs and Sayings', Mokienko V. M. (2008) 'Dictionary of Russian Proverbs', Murrey Yu.V. (2008) 'Russian proverbs, sayings and phraseological units and their English counterparts', Snigerev I. M. (2010) 'Russian folk proverbs and parables'.

A number of scientific disciplines are engaged in the study of mental abilities, intelligence, and intellect: philosophy, logic, psychology, biology, linguistics, etc. This phenomenon is key in the field of cognitive research: Andreyeva Y.A. (2019), Boeckx C. (2010), Chomsky, N. (2006), Chomsky N. (2011), Fujita K. (2009), Gimadeeva A.A. (2019), Greenfield P.M. (1991), Greenfield P.M. (1998), Marantz A. (2005), Poeppel, D. \&. Embick, D. (2005), Poeppel D. (2012), (2019), Tomasello M. (1998) etc.

The practical significance of the work lies in the fact that the results can be used in the development of special courses in comparative paremiology, linguistic folkloristics, linguistic and cultural studies, as well as for foreign students of the languages in question.

This study was carried out in line with two main areas of linguistic culturology paremiological and comparative.

The interest in comparative research is caused by the fact that when studying the foreign languages in question, it will be easier for the student to perceive the language by comparing it with their native language, determining their similarities and differences. Questions of teaching foreign languages, as well as a second language are reflected in the works of Alcón E. \& Guzmán J. (1994), Gass S. \& Varonis E. (1984), Gizyatova L.A. (2018), Lafford B. (2004) and others.

The appeal to paremiological units when expressing stereotypical images formed by representatives of certain cultures and languages seems logical, firstly, due to the proverbiality, secondly, because of the detailed reflection in them relevant to collective native speaker of human behavior patterns, his mental states, etc. Thirdly, paremiological units are valuable for their diversity, and often the polarity of their expressed attitude to certain phenomena of the surrounding world and their assessments. The combination of proverbs around a key component allows us to see the directions of associative understanding of certain properties and qualities of a person (Zangieva, 2014: 115).

According to the Russian scientists, paremias are 'worldview texts which characterize the culture of a people, capable of representing, with a limited number of means, the characteristics of 
the national perception of native speakers' (Balova \& Kremshokalova, 2014: 120). Paremias at the linguistic level reflect elements of ancient culture and national traditions of the people. Being stable phrases, these clichéd units embody the foundations of folk philosophy and psychology. Paremias play the role of 'a kind of repository of information about folk life, a kind of mirror that reflects not only life, but also the history of beliefs, customs and rites of the people (Savenkova, 2002: 8).

A native speaker uses paremias to represent the general standard (stereotypical) opinion of the people, in relation to a specific communication situation. Being statements of an edifying character, paremiological units act as the most effective communication strategies, the knowledge of which is necessary for the student of the language and culture of a particular ethnic group. From the position of cognitive study of discourse analysis, a communication strategy is a kind of prescription regarding the verbal and non-verbal behavior of the producer, aimed at successfully solving the main task of communication is to bring to the recipient information about the need to perform / not perform some action, taking into account the specific situation of reality. The following scientists studied communication strategies: Besolova (2014), Bialystok E. (1990), Canale M. \& Swain M. (1980), Corder S. (1983), Dörnyei Z. \& Thurrell S. (1991), etc.

\section{Methods}

To conduct a systematic analysis of the communicative-pragmatic frame intellect in the English, German and Russian paremiological pictures of the world, the following research methods are used in the article: scientific observation method, comparative method, descriptive method, quantitative calculation method. The direction of the study requires a semantic-cognitive approach. This is due to the fact that the holistic and multifaceted world of the linguistic picture is expressed by the vocabulary used to denote the mental abilities of people. Tokens allow us to reveal the specifics of the national character of a person forming in a culture, the reflection of which are the proverbial sayings of the declared thematic group.

In addition, the article uses the frame analysis method. Paremias, which are the reflection of certain assessments of behavior or social situations, undoubtedly are a typical example of a convention. Being a conventional way of conveying certain meanings and meanings in specific communicative situations, paremias act as means of representing communicative and pragmatic frames. Frames make a big contribution to highlighting the characteristic features of a particular culture. The peculiarities of paremias as frame verbalizers are, first of all, in their ability to reflect and evaluate a stereotypical situation (Semenko, 2010).

Considering the use of frame analysis of paremias, it is advisable to mention the structure of this cognitive phenomenon. Nikonova $\mathrm{Zh}$. V., taking as a basis the study of linguists studying the distinctive characteristics of the frame expression of discourse, points to the following features of the composition of the frames:

'The first property of frames is associated with their ability to interpenetrate; the second concerns the possibility of focusing a person's attention on any part of the frame; the third property introduces the frame directly into the dynamics of thought processes; the fourth property of frames is associated with their dynamic essence as open structures of knowledge that give an idea of typical objects and events; the fifth property of frames concerns the formal presentation of their structure. The top levels of the frame are fixed and correspond to things that are always fair in relation to the proposed situation' (Nikonova, 2008: 10).

Frame analysis allows you to identify the features of the linguistic representation of the frame of the speech acting in paremiological units, which is a meaningful core that includes all possible types of verbalization of the meaning of intentional drawing. 


\section{Results and Discussion}

This article is devoted to a cognitive comparative analysis of a binary opposition intellect foolishness in English, German and Russian proverbs and sayings. Communicative and pragmatic frames intellect and foolishness are objectified in proverbs and sayings by means of explication of stereotypical evaluation criteria in relation to mental abilities of a man.

The interest in paremias with this semantics is due to the significance of the people's understanding of human intelligence as one of the main characteristics of a contemporary worldview.

Intellect is embodied and reflected in person's mind and constitutes 'a complete unity along with the soul and the heart. Without keen intellect one cannot become wise' (Kolesov, 2002: 102). In some research intellect is defined as 'a reflection of the level of cognitive development of a person reached by a certain age, manifested in the formation of cognitive functions, in the degree of assimilation of mental skills and knowledge, and which is used to achieve much success in various activities and to adapt to the environment successfully' (Teliya, 1986: 36).

The mental stereotypes represented in English, German and Russian proverbs and sayings are considered to be a set of characteristics which affect the assessment of the level of people's intellectual abilities. Communicative and pragmatic frame intellect includes the following criteria, explicated in the considered paremias - wit/mind, wisdom, knowledge, education and experience.

Considering the frame structure of the conceptual opposition intellect-foolishness in English, German and Russian paremiological world pictures (PWP), we have marked the following opposite slots represented in Table 1 bellow.

Table 1.

\begin{tabular}{|c|c|c|c|c|c|}
\hline \multicolumn{2}{|c|}{ English PWP } & \multicolumn{2}{|c|}{ Russian PWP } & \multicolumn{2}{|c|}{ German PWP } \\
\hline a wise man & a fool & $\begin{array}{c}\text { мудрец (мудрый } \\
\text { человек) / a wise } \\
\text { man }\end{array}$ & дурак / a fool & $\begin{array}{l}\text { Kluge / a } \\
\text { clever man }\end{array}$ & Narr / a fool \\
\hline wise & foolish, mad & умный / clever & $\begin{array}{l}\text { глупый / } \\
\text { foolish }\end{array}$ & klug / clever & $\begin{array}{l}\text { dumm / } \\
\text { foolish }\end{array}$ \\
\hline wit, mind, brains & little wit & $\begin{array}{l}\text { разумный / } \\
\text { intellectual }\end{array}$ & $\begin{array}{c}\text { безумный / } \\
\text { mad }\end{array}$ & $\begin{array}{c}\text { weise / wise, } \\
\text { gescheiter / } \\
\text { sensible, } \\
\text { intelligent }\end{array}$ & $\begin{array}{l}\text { närrisch / } \\
\text { foolish }\end{array}$ \\
\hline knowledge & $\begin{array}{c}\text { little } \\
\text { knowledge }\end{array}$ & $\begin{array}{l}\text { ум / wit, mind, } \\
\text { brains }\end{array}$ & $\begin{array}{l}\text { глупость / } \\
\text { foolishness }\end{array}$ & $\begin{array}{l}\text { Klugheit / wit, } \\
\text { mind, brains }\end{array}$ & $\begin{array}{l}\text { Dummheit, } \\
\text { Narrheit / } \\
\text { dullness, } \\
\text { stupidity }\end{array}$ \\
\hline taught & $\begin{array}{l}\text { ill taught, } \\
\text { untaught }\end{array}$ & $\begin{array}{c}\text { ученье / learning, } \\
\text { studies }\end{array}$ & $\begin{array}{c}\text { невежество / } \\
\text { ignorance }\end{array}$ & $\begin{array}{l}\text { Gelehrte / } \\
\text { scientist }\end{array}$ & --- \\
\hline learning, studies & -- & знание / knowledge & -- & $\begin{array}{l}\text { Erfahrung / } \\
\text { experience }\end{array}$ & --- \\
\hline
\end{tabular}

The examples represented in the table demonstrate lexical oppositions used in proverbs and sayings. These contrasts are represented by antonyms, contextual antonyms and conversions. Proverbial oppositions based on polar oppositions are one of the most commonly used means of expressing the binom intellect - foolishness. However, as it can be seen from Table 1, not all words have the opposite meaning in the considered paremiological units (Table 1).

The analyzed material allowed us to distinguish the following main semantic groups characterizing the assessment of mental abilities of representatives of English, German and Russian paremiological world pictures:

1. The importance of intellect.

2. Studies and knowledge. 
3. A fool stays a fool.

4. Fools are always happy / lucky.

5. A fool can be right.

6. A clever man may make mistakes.

7. A clever man does not try to look cleverer.

8. A fool tries to look cleverer.

The first semantic group The Importance of Intellect is represented by the majority of all the studied paremias - 17\% of all the English proverbs, $14 \%$ of the German proverbs, and $15 \%$ of the Russian proverbs (Bar Chart 1).

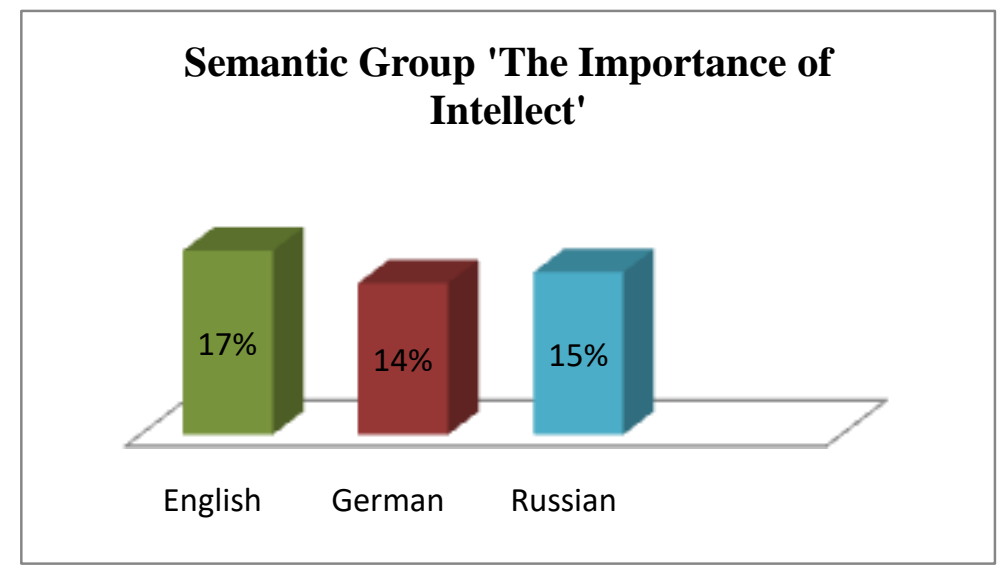

Bar Chart 1.

In the studied paremiological world pictures, intellect is considered the most important factor which determines a person's personality. The paremias also emphasize the superiority of intellect over appearance, wealth, and strength: A wise man cares not for what he cannot have (Bryan G. B. \& Mieder W., 2005: 218), Adversity makes a man wise, though not rich (Bryan \& Mieder, 2005: 135), Full bellies make empty skulls (Bryan \& Mieder, 2005: 209), The brains don't lie in the beard (Murrey, 2008: 23), Under a ragged coat lies wisdom (Murrey, 2008: 155), Wisdom is better than strength (Murrey, 2008: 82), Without wisdom, wealth is worthless (Murrey, 2008: 154); Борода уму не замена - A beard can't be a substitute for a man's brain (Murrey, 2008: 23), Живот толстой, да лоб пустой - His stomach is full, but his head is empty (Murrey, 2008: 73), Не всяк умен, кто с головою - Hе has a head but it doesn't mean he is clever (Snigerev, 2010: 140), Нищета не отнимет ни чести ни ума-Poverty doesn't mean that one cannot be honest and clever (Snigerev, 2010: 155); Wo einer Weise ist, sind zweie glücklich Where there is wisdom, the two are happy (Beyer \& Beyer, 1987: 168), Kluger Tadel ist bittere Arznei-A smart censure is a bitter medicine (Beyer \& Beyer, 1987: 317), Lieber ein kluger Tadel als ein dummes Lob - It is better to receive a smart censure than a stupid praise (Beyer \& Beyer, 1987: 317), Ein Erfahrener ist besser als zehn Gelehrte - One experienced man is better than ten scientists (Simrock, 2015: 39), Lehren bringt Ehren - Sdudies bring honour (Simrock, 2015: 90), Dem klugen Kopfe genügt ein Wort - For s smart person just one word seems enough (Beyer\& Beyer, 1987: 316), Aus schlichtem Haus sieht oft ein kluger Mann heraus - Don't judge a man by his appearance (Beyer\& Beyer, 1987: 316).

Paremiological units that reveal the attitude to study (knowledge) constitute $17 \%$ in English, 10\% in German and 8\% in Russian paremiological world pictures (Bar Chart 2). 


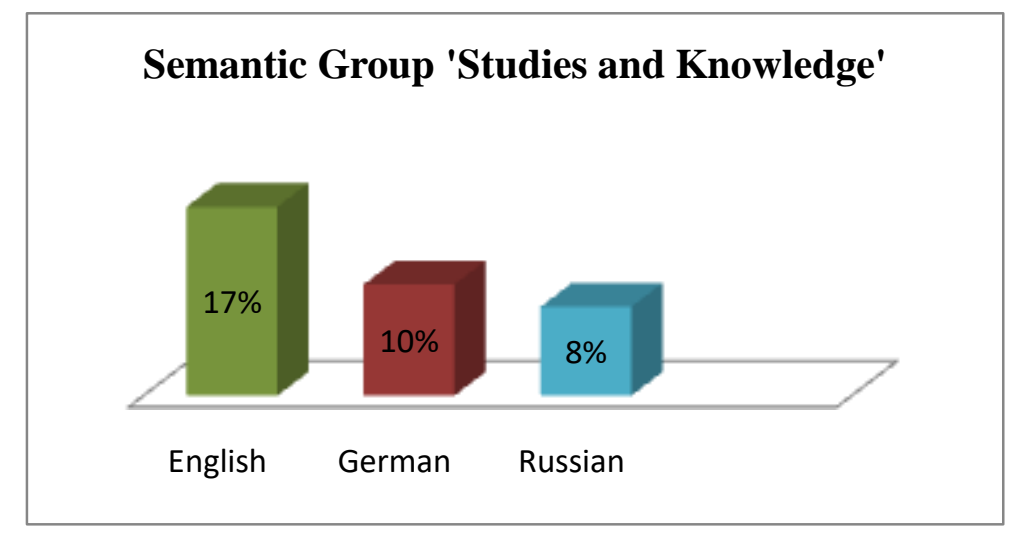

Bar Chart 2.

The majority of the proverbs and sayings represent a positive attitude towards learning: $A$ belly full of gluttony will never study willingly (Murrey, 2008: 209), A little knowledge is a dangerous thing (Murrey, 2008: 152), Better untaught than ill taught (Bryan \& Mieder, 2005: 152), Knowledge is no burden (Bryan \& Mieder, 2005: 80), Knowledge is power (Bryan \& Mieder, 2005: 80), Learning is the eye of the mind (Bryan \& Mieder, 2005: 21), Live and learn (Murrey, 2008: 33), Never too old to learn (Murrey, 2008: 61), Ученье свет, а не ученье тьмаStudies are light whereas ignorance is darkness (Murrey, 2008: 219), Сытое брюхо к ученью глухо - A belly full of gluttony will never study willingly (Murrey, 2008: 209), Век живи - век учись - If уои live long then study long (Murrey, 2008: 303), Для ученья нет старости - No one can be too old to study (Snigerev, 2010: 61), Знания никому не в тягость - Knowledge cannot be a burden to anyone (Snigerev, 2010: 80); Es fällt kein Gelehrter von Himmel - No scientist has fallen down from the sky (Simrock, 2015: 54), Lehren bringt Ehren - Studies bring honour (Simrock, 2015: 90), Man lernt, solange man lebt - One studies as long as he lives (Simrock, 2015: 91), Übung ist die beste Schulmeister - Exercises are the best teacher (Beyer \& Beyer, 1987: 107), Buch macht klug -A book makes you clever (Beyer \& Beyer, 1987: 316).

A constituent part of this semantic subcategory in the corpus of German paremias is the value concepts craftsmanship and experience: Lehrjahre sind keine Meisterjahre - Years of study are not years of master (Simrock, 2015: 90), Wer sein eigener Lehrmeister sein will, hat einen Narren zum Schüler - If you want to be a teacher you should have a fool as your student (Simrock, 2015: 90), Es ist noch kein Meister vom Himmel gefallen - No scientist has fallen down from the sky (Simrock, 2015: 54), Ein Erfahrener ist besser als zehn Gelehrte - One experienced man is better than ten scientists (Beyer \& Beyer, 1987: 203), Durch Schaden wird man klug - Mistakes make you smart (Beyer \& Beyer, 1987: 317), Erfahrung macht klug Nersuch macht klug - (букв.) Experience makes you clever (Beyer\& Beyer, 1987: 317), Vom Narren lernt der Kluge seine Weisheit - (literally) The clever one gets his wisdom from the mistakes of the fools (Beyer\& Beyer, 1987: 418).

Nevertheless, there are single proverbs reflecting a negative attitude towards learning in the studied paremiological world pictures: Much learning make men mad (Bryan \& Mieder, 2005: 82), Much science, much sorrow (Bryan \& Mieder, 2005: 119), И от ума сходят с ума-Mисh learning make men mad (Snigerev, 2010: 82), Lerne, so kannst du was vergessen - Learn then you will have something to forget about (Simrock, 2015: 91), Bücher machen Narren und Weise Books make both fools and sages, или другое значение - Fools and sages write books (Beyer \& Beyer, 1987: 416).

The existence of opposite in meaning paremias (antonymy) is explained by the inconsistency of the human mentality as a whole, as well as the reflection in the proverbs and sayings of the views of various social groups.

The next semantic group concerns people with low level of intelligence. In the tree studied paremiological world pictures, there is a stereotype according to which the lack of mental abilities is a constant characteristic of an individual, in other words, a fool always stays a fool. It should be 
pointed out that English and German proverbs which express this belief constitute 12,5\% and $12 \%$ of the paremias, while the corpus of Russian proverbs and sayings includes only $8 \%$ of such paremias (Bar Chart 3).

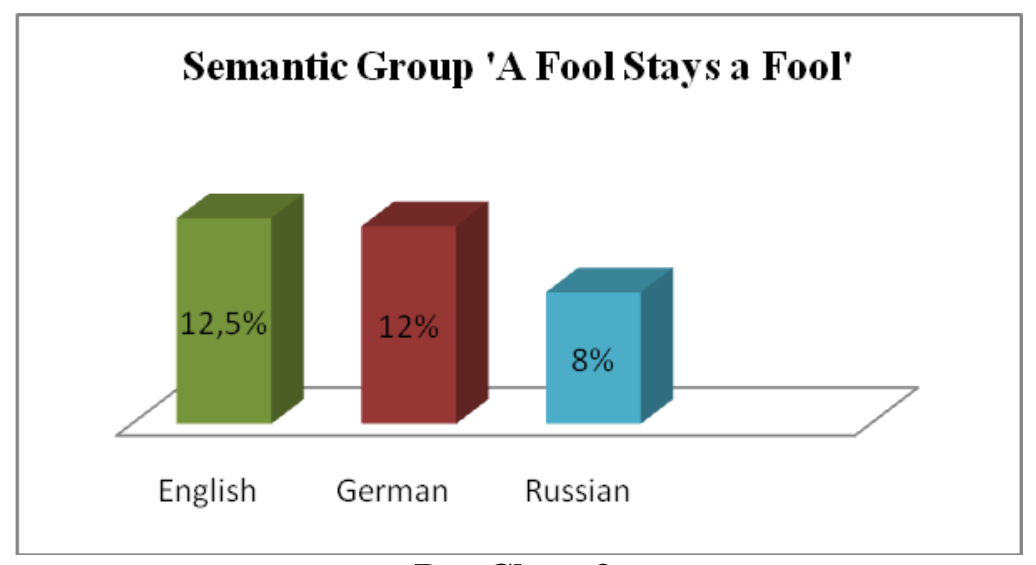

Bar Chart 3.

According to the examined proverbs, one cannot become cleverer if he has never been smart enough: If an ass goes a-travelling, he'll not come home a horse (Bryan \& Mieder, 2005: 39), Send a fool to France and a fool he will return again (Bryan \& Mieder, 2005: 217), A carrion kite will never be a good hawk (Mieder, 2008: 39), A fool at forty is a fool indeed (Mieder, 2008: 31), An ape's an ape, a varlet's a varlet, though they be clad in silk or scarlet (Murrey, 2008: 88), An ass is but an ass, though laden with gold (Mieder, 2008: 91), Fools will be fools still (Mieder, 2008: 67), He that is born a fool is never cured (Murrey, 2008: 67), Как свинью в кафтан не ряди, она свиньей и останется - A pig is a pig, though dressed up [6, с. 88], Ум за морем не купишь, коли его дома нет - (literally) You cannot buy intellect abroad if you don't have it at home (Mokienko et. al., 2008: 217), Ворона и за море летала, да вороной и вернулась - A crow has gone overseas but has returned home a crow (Anikin, 1988: 39), Вороне соколом не бывать - A crow will never be a hawk (Anikin, 1988: 39); Wenn man einen Narren im Mörser zerstieße, so ließe doch seine Narrheit nicht von ihm - (literally) Even if you grind a fool in a mortar, he won't stop being stupid (Beyer \& Beyer, 1987: 106), Dumm geboren, dumm geblieben - He that is born a fool will die a fool (Beyer \& Beyer, 1987: 112), Ein Esel bleibt Esel, käm' er auch nach Rom - An ass will stay an ass though he's been sent to Rome (Beyer, 1987: 39), Ein Esel ging in die Fremde, und ein Esel kam heim - An ass went travelling and he came home being an ass (Beyer \& Beyer, 1987: 139), Wie ein Narr begonnen, wie ein Narr beendet - (literally) He that started being a fool, finished being a fool (Beyer \& Beyer, 1987: 419).

Moreover, the English, German and Russian proverbs demonstrate a stereotype in accordance with which stupid people are considered to be much happier than clever and wise ones. The semantic group Fools are always happy / lucky is presented by 11\% of the English proverbs, $10 \%$ of the German proverbs and 5\% of the Russian ones (Bar Chart 4).

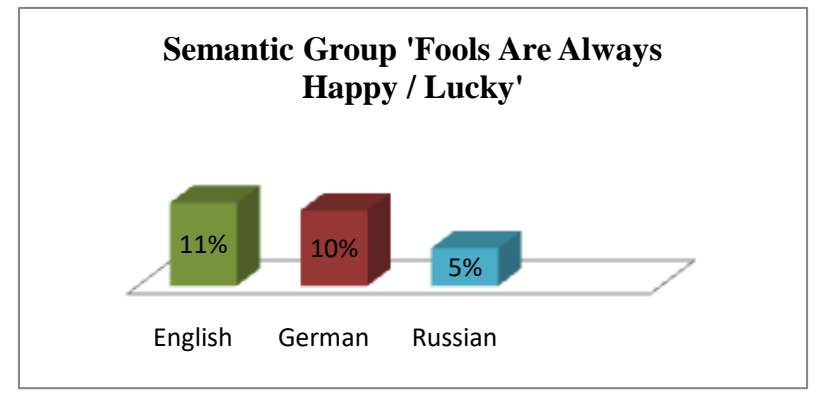

Bar Chart 4. 
The following examples represent this semantic group: Fools rush in where angels fear to tread (Murrey, 2008: 311), Children and fools have merry lives (Murrey, 2008: 67), Fools for luck (Bryan \& Mieder, 2005: 208), Fortune favours fools (Mieder, 2008: 208), God sends fortune to fools (Bertram, 1993: 208); Дуракам во всем счастье - Fools are always happy in everything (Mokienko et. al, 2008: 67), Дураком на свете жить - ни о чем не тужить - A fool lives lifeheartedly (Mokienko et. al, 2008: 67), Меньше знать - крепче сnать - The less you know the better you sleep (Murrey, 2008: 119), На дурака у Бога милости много - God is kind to fools (Anikin, 1988: 129); Die Narren haben das beste Leben - Fools have better lives (Beyer \& Beyer, 1987: 416), Ein Narr hat die schöne Welt - A fool lives in a wonderful world (Beyer \& Beyer, 1987: 317), Dummheit ist auch eine Gabe Gottes, aber man muss sie nicht missbrauchen Foolishness is a God's gift but an excessive use of it won't do you any good (Simrock, 2015: 40), Den Narren macht die Hoffnung reich - Hope makes a fool rich (Beyer, 1987: 416), Dem Dummen hilft der liebe Gott - God helps fools (Beyer \& Beyer, 1987: 113), Die Dümmsten haben das meiste Glück - Fools are always the luckiest (Beyer \& Beyer, 1987: 113), Narren lassen sich keine grauen Harre wachsen - Fools never have gray hair (Beyer \& Beyer, 1987: 417), Gluck ist Dummen Vormund - Happiness is a fool's guardian (Simrock, 2015: 58).

The semantic groups A fool can be right and A clever man may make mistakes are the opposites in some way. The English and Russian corpuses contain roughly the same amount of proverbs reflecting these ideas - 9\% of the English proverbs and $8 \%$ of the Russian ones represents the idea of a silly person who once in a while can say a right thing. The German corpus of the examined proverbs on the problem is represented by only one proverb which constitutes $0,2 \%$ (Bar Chart 5).

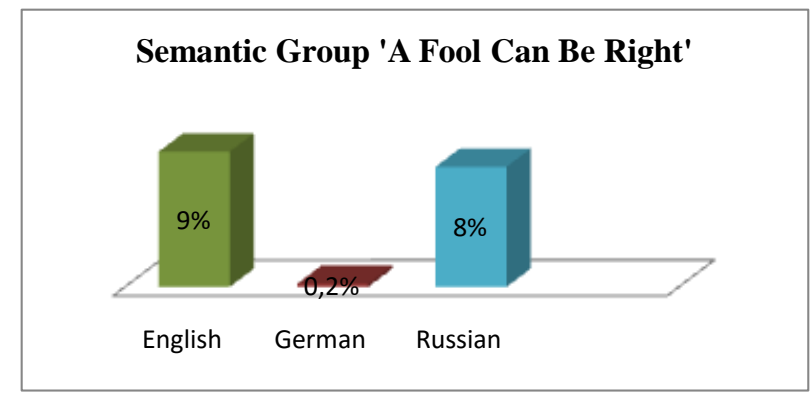

\section{Bar Chart 5.}

At the same time 15\% of German proverbs and $8 \%$ of both Russian and English proverbs carry the idea of a clever man making mistakes (Bar Chart 6).

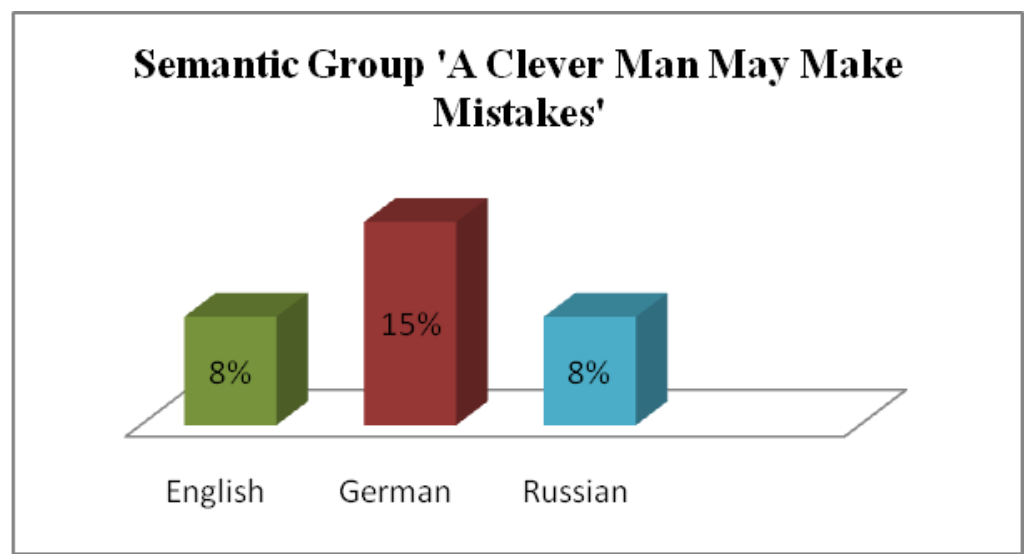

\section{Bar Chart 6.}

The following proverbs depict the idea discussed above: A fool may give a wise man council (Mieder, 2008: 85), A fool may sometimes speak to the purpose (Bryan \& Mieder, 2005: 
40), A fool may sometimes tell the truth (Murrey, 2008: 40), Иной раз и дурак молвит слово в лад -A fool may sometimes say something clever (Mokienko et. al, 2008: 85), Бblвaem, что u дурак умного надувает - A fool may sometimes cheat (Anikin, 1988: 25). No man is wise at all times (Bertram, 1993: 36), Though old and wise, yet still advise (Murrey, 2008: 81), И мудрому человеку совет требуется (Mokienko et. al, 2008: 81), И на большие умы живет расход - A clever man may sometimes make a mistake (Murrey, 2008: 82).

As far as the German language is concerned, we have found only one proverb which carries the idea of a stupid man being right: Auch ein Narr kann einmal ein kluges Wort reden - A fool may sometimes tell the truth (Beyer \& Beyer, 1987: 316). Большая часть немецких пословиц (это $15 \%$ ) в рамках рассматриваемой бинарной оппозиции направлена на оправдание возможных ошибок мудрых, умных людей: Gescheite Hahnen frisst der Fuchs auch - (literally) A fox may even eat clever cocks (Simrock, 2015: 56), Auch kluge Hühner scheissen sich ins Nest - (literally) Clever hens may sometimes defecate in their nests (Beyer \& Beyer, 1987: 316). Auch kluge Vögel werden gefangen - Clever birds may sometimes be caught (Beyer \& Beyer, 1987: 316), Kluge Leute irren auch- умные люли тоже ошибаются (Beyer \& Beyer, 1987: 316). Kluge Leute machen auch wohl dumme Streiche - Clever people may sometimes behave foolishly (Beyer \& Beyer, 1987: 317), Niemand ist zu allen Zeiten klug Никто не бывает всегда умен попадаются (Beyer \& Beyer, 1987: 317), Auch der Klügste kann irren - И самый умный ошибается попадаются (Beyer \& Beyer, 1987: 316), Keiner ist so klug, dass nicht ein wenig Narrheit übrig hätte - None is so clever that there is not a little foolishness left (Beyer \& Beyer, 1987: 317).

Semantic groups describing stereotypes related to the behavior of clever and stupid people play an important role in shaping the worldview of the examined ethnic groups. Having studied the paremiological units of the English, German and Russian languages, we can conclude that the standard ideas of the peoples about the behavior of individuals coincide. The semantic group $A$ clever man does not try to look cleverer is presented by $6 \%$ of English proverbs, $8 \%$ of German proverbs and $4 \%$ of Russian proverbs (Bar Chart 7).

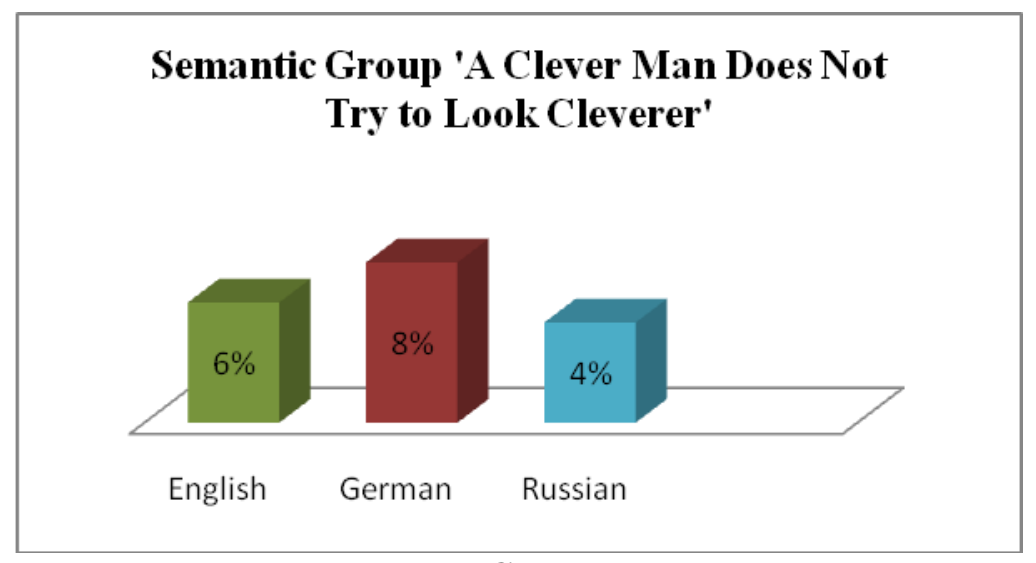

Bar Chart 7.

This semantic group expresses the opinion of the English, German and Russian peoples that a person who possesses high mental abilities behaves modestly, tends not to boast of his knowledge and prefers to keep silence: A still tongue makes a wise head (Mieder, 2008: 51), Who knows most, speaks least (Mieder, 2008: 100); Говори меньше, умнее будет - Speak less and уои will be cleverer (Aniken, 1988: 51), Кто много знает, тот мало болтает - Who knows most, speaks least (Mokienko et. al., 2008: 100), Кто молчит, тот двоих научит - Hе that keeps silence can teach others (Murrey, 2008: 101), Умный молчит, когда дурак ворчит - A clever man keeps silence while a fool grumbles (Mokienko et. al., 2008: 105), Умный не тот, кто много говорит, а тот, кто много знает - Hе is not clever that speaks much but he is clever that knows much (Murrey, 2008: 102); Ein Genie braucht keinen Adelsbrief - A genius doesn't need a title deed (Beyer \& Beyer, 1987: 218), Es schweigen mehr kluge Leute als dumme - Clever people keep silence more often than fools do (Beyer \& Beyer, 1987: 316), Kluges 
Schweigen ist besser als dummes Reden - Clever silence is better than a stupid speech (Beyer \& Beyer, 1987: 317), Klug reden ist schwer, schweigen noch mehr - It's difficult to speak wisely but to keep silence is even more difficult (Beyer \& Beyer, 1987: 317), Unter Schwätzen ist Schweigen das klügste - The cleverest thing while chatting is to keep silence (Beyer \& Beyer, 1987: 317).

On the contrary, representatives of the described ethnic groups are convinced that the lower the person's intelligence, the more he speaks and the more immodest his behaviour is. This stereotype is represented in paremias included into the semantic group A fool tries to look cleverer. The German corpus contains $10 \%$ of such proverbs, while the English and the Russian ones embody $6 \%$ and $4 \%$ respectively (Bar Chart 8 ).

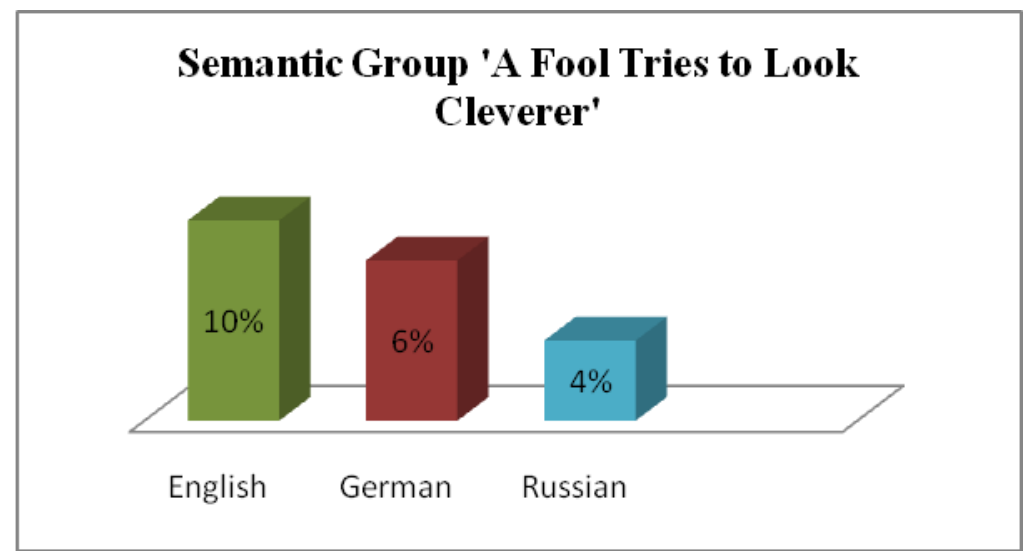

Bar Chart 8.

Here are the examples of the proverbs belonging to the semantic group: A fool always rushes to the fore (Bryan \& Mieder, 2005: 51), Foolish tongues talk by the dozen (Mieder, 2008: 51), Wise men silent, fools talk (Bertram, 1993: 218); Азбуки не знает, а читать садится - Не doesn't know the alphabet but tries to read (Murrey, 2008: 8), Глупый болтает, умныии думает - A fool speaks while a clever man thinks (Aniken, 1988: 51), Глупьй ищет большого места, а умного и в углу видать - (literally) A fool always looks for a big place while a clever man can be seen even in the corner (Mokienko et. al., 2008: 51); Glocken und Narren läuten gern - (literally) Both bells and fools ring with pleasure (Simrock, 2015: 58), Ein Narr kann mehr fragen als sieben Weisen sagen - A fool asks more questions than ten wise men can answer (Beyer \& Beyer, 1987: 106), Ein Narr, der fragen darf, sieht gescheiter aus als ein Gescheiter, der antworten muss - A fool who is allowed to ask looks cleverer that a wise man who is to answer (Beyer \& Beyer, 1987: 106), Allzu pfiffig ist nicht klug - Too clever doesn't mean wise (Beyer \& Beyer, 1987: 316), Jeder hält sich kluger, als er ist - Everyone thinks himself cleverer than he is (Beyer \& Beyer, 1987: 317), Wenn der Dumme schweigt, gilt er für klug - A fool that keeps silence may pass for a clever man (Beyer \& Beyer, 1987: 416), Der Kluge gibt nach, der Vernünftige denkt nach; der Weise spürt nach, der Einfältige ahmt nach; der Narr spricht nach, der Tor jagt nach - A clever man gives in, a reasonable one reflects a wise one follows, a simple-hearted one imitates, a fool replicates and a dumbhead chases (Beyer \& Beyer, 1987: 317), Je leerer der Kopf, desto lauter das Maul - (literally) The emptier the head, the louder the mouth (Beyer \& Beyer, 1987: 324), Wo es an verständigen Männern fehlt, steigen die Narren im Kurse - If there are no clever people to rule then fools start ruling (Beyer \& Beyer, 1987: 417).

In the studied languages certain figuratively associative stereotypes have developed and subsequently entrenched in the course of many centuries of folk art. In English, German and Russian, one can find names of animals which are associated with mental abilities. Sheep and ass are the most frequent zoomorphic components of the paremiological units which are used to express stupidity in the German language:

So dumm als ein Hinterviertel vom Schafe - (literally) As stupid as the mutton's leg (Simrock, 2015: 32), Ein Schaf schickt man, ein Kalb kommt wieder heim - A ram left and came back home as a calf (Beyer \& Beyer, 1987: 490), Ein gutes Lamm, ein dummes Schaf - A good lamb but a stupid ram (Beyer \& Beyer, 1987: 112), Der Esel weiss auch was - An ass may know 
something (Beyer \& Beyer, 1987: 139), Ein Esel kraut den anderen - A fool praises a fool (literally - One ass pets another one) (Beyer, 1987: 139), Es ist ein Esel, der mit einem Esel streitet - He is an ass that argues with an ass (Beyer \& Beyer, 1987: 139), Wir Gelehrten wissen schon, was gut schmeckt, sagte der Esel zum Schaf, als er nach einer Distel schnappte - 'We, real scientists, know what dishes are tasty', said the ass to the ram and started eating thistles (Beyer \& Beyer, 1987: 203).

There are also English and Russian proverbs which contain the zoomorphic component ass: An ass is but an ass, though laden with gold (Bertram, 1993: 91), If an ass goes a-travelling, he'll not come home a horse (Bertram, 1993: 91); Велик осел, да воду возит; мал сокол, да на руках носят - (literally) An ass is big but it's used to carry water while a hawk is small but it is carried in arms (Murrey, 2008: 114). However, the following in frequency in English and Russian is the slot ape: An ape's an ape, a varlet's a varlet, though they be clad in silk or scarlet (Murrey, 2008: 88); Мартышка и без хвоста всё равно мартышка - An ape without a tail is still an ape (Murrey, 2008: 92). Besides, we have uncovered the slots crow and carrion crow in the English and Russian paremiological world pictures: A carrion kite will never be a good hawk (Mieder, 2008: 119); Ворона и за море летала, да вороной и вернулась - A crow has gone overseas but has returned home a crow (Murrey, 2008: 39), Вороне соколом не бывать - A crow will never become a hawk (Murrey, 2008: 39).

It has been found out that in the Russian paremiological world picture the zoomorphic component pig is given a special attention to describe mental abilities of a person: Как свинью в кафтан не ряди, она свиньей и останется - A pig is a pig, though dressed up (Murrey, 2008: 88), На свинью хоть хомут надень, всё конём не будет - Even if уои put a collar on a pig, уои won't make it a horse (Murrey, 2008: 39).

The results of the study demonstrate the fact that proverbial stereotypes about person's mental abilities are very similar in the English, German and Russian paremiological world pictures. However, we have also revealed semantic lacunas in the studied languages. For example, the negative influence of alcohol is explicated in the proverbs of the studied languages: When wine is in, the wit is out (Mieder, 2008: 35), Вино входит - ум выходит - When wine is in, the wit is out (Murrey, 2008: 35); Der Wein macht kluge Leute zu Narren - Wine turns clever people into fools (Beyer \& Beyer, 1987: 317), Viel Wein macht dumme Leute - (literally) - Much wine makes fools (Beyer \& Beyer, 1987: 113), Beim Trunk erkennt man den Narren - A fool can be recognized when he is drunk (Beyer \& Beyer, 1987: 416), Bei Narren, Kindern und Wein kann nichts lange verborgen sein - You will never keep anything secret in the company of fools, children and wine (Beyer \& Beyer, 1987: 416). However, we have revealed English and German proverbs which demonstrarte an opposite stereotype: Who doesn't love wine, women and song, remains fool his whole life long (Mieder, 2008: 127), Wer nicht liebt Wein, Weib und Gesang, der bleibt ein Narr sein Leben lang - He that doesn't love wine, women and songs will remain fool his whole life long (Beyer \& Beyer, 1987: 417). This proverb expresses the opinion of the English and German peoples that only a complete fool cannot like wine, women and songs.

It should be stressed that attitude to the elderly and old age in the studied languages is completely different. We have found English proverbs which express a positive attitude towards old age and worldly experience: Experience is the mother of wisdom (Bertram, 1993: 81), If you wish a good advice, consult an old man (Mieder, 2008: 22). However, old age is considered to be a drawback in the Russian world picture: Cтарые дураки глупее молодых - Old fools are more stupid than young ones (Anikin, 1988: 206). The German proverbial corpus contains both negative and positive proverbs: Die Klugheit ist die Tapferkeit der Alten - Intellect is old men's courage (Beyer \& Beyer, 1987: 318), Ein alter Narr wird selten klug - An old fool hardly ever become wise (Beyer \& Beyer, 1987: 417), Die Zeit macht auch den Narren klug - Time may make a fool clever (Beyer \& Beyer, 1987: 417), Je älter, je dümmer - The older, the sillier (Beyer \& Beyer, 1987: 39).

Paremias, representing the connection between mental abilities and material well-being reflect opposite points of view. 
The Russian paremias, such as Богата, хоть дурака, всяк почитает - A rich fool always has the honour (Mokienko et.al., 2008: 21), Умом туn, да кошелек туг - Не is a fool but his wallet is full (Mokienko et.al., 2008: 316) reflect the stereotype that a materially well-off person is worthy of respect, despite his low level of mental abilities. In turn, the English proverb He is wise that is rich (Murrey, 2008: 18) expresses the idea that a person does not need to be clever to become wealthy. Схожую семантику имеет немецкая паремия Je reicher, je klügerThe richer, the cleverer (Beyer \& Beyer, 1987: 317). Consequently, unlike the British and Germans, the Russian people admit that a fool can be rich.

In this slot, the characteristic German language is the differential seme 'knowledge above wealth': Kenntnis geht über Reichtum - Knowledge is more important than wealth (Beyer \& Beyer, 1987: 307), Das Amt macht wohl satt, aber nicht klug - A position makes your stomach full but it doesn't make you clever (Simrock, 2015: 316).

Another semantic lacuna can be found in the Russian paremiological world picture. It is represented by the attitude of the Russians to happiness and intelligence: Иногда горсточка счастья лучше воза ума - Sometimes it's mисh better to be a bit happy than very clever (Murrey, 2008: 85), Счастье дороже ума - Happiness is worth more than intellect/mind (Murrey, 2008: 208). Despite the fact that intelligence is considered as one of the most important components of personality formation, for the Russian people, happiness is a state of a person in which the most important quality (intelligence) is considered less significant. In the English and German paremiological world pictures no paremias with similar semantics were found.

Considering the proverbs from the point of view of speech impact, Issers O.M. points out that 'the implementation of speech exposure occurs by means of speech strategies, which are a common line of behavior of the communicant, chosen consciously or automatically and aimed at influencing the consciousness of the interlocutor' (Isser, 2008: 64). Among the English, German and Russian paremias containing the nomination of the binomial intellect - stupidity proverbs were found that belong to the group of regulations (utterance of advice, motives, etc.). These paremiological units used by the speaker influence the listener, acting as a communicative speech strategy: Lass dem Narren seine Weise - Leave a fool with his truth (Beyer \& Beyer, 1987: 418), Denke langsam, handle schnell - Think slowly but act quickly (Beyer \& Beyer, 1987: 418), Denk, was du willst, und iss, was su hast - Think what you want, eat what you have (Beyer \& Beyer, 1987: 418), Denke zweimal, eh'du einmal sprichst - Think twice before you start talking (Beyer, 1987: 418), Erst denken, dann handeln - Think first then do (Beyer \& Beyer, 1987: 418); Learn to say before you sing (Murrey, 2008: 8), Learn weeping, and you shall gain laughing (Mieder 2008: 146), If you wish a good advice, consult an old man (Mieder 2008: 22); Пей Еремей, да ума не nponeŭ - Drink Eremey (Eremey is a man's name) but don't drink your mind away (Snigerev, 2010: 366), Век живи - век учись - Live long and learn long (Murrey, 2008: 33), Дай глупому лошадь, он на ней и к черту уедет - Give a fool a horse and he will go right to the devil's (Murrey, 2008: 55), Дай дураку веревку, он и повесится - Give a fool a piece of a rope and he will hang himself (Murrey, 2008:55), Дурака пошли, да сам следом иди-Send a fool but follow him (Murrey, 2008: 67).

\section{Summary}

Proverbs and sayings are of great importance in preserving the national identity of the linguistic culturology of the ethnos, since 'they convey the specifics of understanding the world, human understanding of nature, the laws of human life, social rules and awareness of their values' (Kondrateva, 2007: 14). They reflect the specific ethnic features of the linguistic picture of the world, its unique cultural meanings. The significance of paremias is due to the fact that the proverbial picture of the world is part of the conceptual sphere of the ethnos, which reflects the key values of the people (in particular, the values associated with the society, the nature and people themselves). Proverbs convey a moral message. They are represented in a form of a recommendation or a piece of advice. It allows us to consider them as a source of understanding of human society and the relationships in it and as a kind of valuable didactic material. According to Vezhbitskaya A. 'the wishes contained in proverbs and sayings have existed for more than a 
century, and despite all the changes that have occurred in our society over the past century, they are still a universal source of comprehension of the ethical norm and thinking of the people' (Vezhbitskaya, 2001: 29). It follows that proverbs and sayings are of particular importance for understanding the axiological representations of an ethnos, which are historically overestimated depending on the socio-cultural experience of the nation. One of the important axiological indicators of linguistic culture is the concept of "mind". The value significance of the mind is reflected in the proverbial foundation of peoples rather inconsistently, due to the fact that the idea of the mind in general in the linguistic picture of the world is quite contradictory.

\section{Conclusion}

The created image of a person in the linguistic world picture of each nation consists of many criteria, the most important of which is given to stereotypical ideas about mentality,mental abilities of ethnic groups. Describing the frame as a system of data on the stereotypical situation (estimates), we substantiated the feasibility of using the frame analysis in the study of proverbs as verbalizers of the communicative and pragmatic frame intellect-foolishness.

To identify the characteristic features of the frame structure of the conceptual opposition intellect - foolishness in the English, German and Russian paremiological pictures of the world, opposite slots were allocated; as well as semantic groups characterizing the assessment of mental abilities of representatives of English, German and Russian paremiological world pictures. Besides, in the course of this study, we identified both universal and unique stereotypical assessments of the mental abilities of representatives of the English, German and Russian peoples, represented in the paremiological units of the ethnic groups. According to the study, the proverbial stereotypes in relation to the mental abilities of peoples (the value of the availability of knowledge, intelligence; the relationship between the level of mental abilities and behavior, luck) mainly coincide. It should be stressed, that the points of view of the ethnic groups in relation to the dependence of intelligence on alcohol, age, wealth and happiness are different. In the English and German paremiological world pictures the attitude towards these semantic groups are mainly identical. However, the study of paremiological units of the Russian language, revealed opposing stereotypes, as well as lacunas. These research results are due to the relatedness of English and German, included in the German language group. In turn, the Russian language is a representative of the Slavic language group.

\section{Acknowledgements}

The work is performed according to the Russian Government Program of Competitive Growth of Kazan Federal University.

\section{References}

Alcón, E., \& Guzmán, J. (1994). Interlanguage modifications in NS-NNS oral interactions: A study in an English and Catalan learning context. Revista Española de Linguistica Aplicada, 10, 17-26.

Andreyeva, Y.A., Korneva, I. G., \& Sakhibullina, K. A. (2019). Values and Anti-Values in Figurative Phraseological Units in the Russian and German Languages. Humanities \& Social Sciences Reviews, 7(4), 427-432.

Anikin, V.P. (1988). Russian Proverbs and Sayings. Moscow, Khudozhestvennaya Literatura, 431 p.

Balova, I.M., \& Kremshokalova, M.Ch. (2011). Paremias as a Form of Synthesis of Semantic Worlds of Russian and Caucasian Cultures, Culture and Identity, 1, 108-124.

Bertram, A. (1993). NTC's Dictionary of Proverbs and Cliches. Lincolnwood, Illinois: NTC Publishing Group, 333 p.

Besolova, E.B. (2014). Reflection of the System of Worldview Knowledge of the Ossetians in the Language and its Cognitive Structure . Izvestiya SOIGSI, 14(53), 63-72. 
Beyer, H., \& Beyer, A. (1987). Sprichwörterlexikon - Sprichwörter und sprichwörtliche Ausdrücke aus deutschen Sammlungen. Vom 16. Jahrhundert bis zur Gegenwart. 3. Auflage. Bibliographisches Institut Leipzig, $712 \mathrm{~s}$.

Bialystok, E. (1990). Communication Strategies. A Psychological Analysis of Second-language Use. Oxford: Basil Blackwell, 163 p.

Boeckx, C. (2010). Language in Cognition. Uncovering Mental Structures and the Rules Behind them. Malden, MA.: Wiley-Blackwell, $264 \mathrm{p}$.

Bryan, G.B., \& Mieder, W. (2005). Anglo-American Proverbs and Proverbial Phrases Found in Literary Sources of the Nineteenth and Twentieth Centuries. New York: Peter Lang Publishing, $870 \mathrm{p}$.

Canale, M., \& Swain, M. (1980). Theoretical Bases of Communicative Approaches to Second Language Teaching and Testing. Applied Linguistics, 1(1), 1-47.

Chomsky, N. (2006). Biolinguistics and the Human Capacity. In: Chomsky N., Language and Mind. Cambridge: Cambridge University Press, 39 p.

Chomsky, N. (2011). Language and Other Cognitive Systems. What is Special About Language?. Language Learning and Development, 7, 263-278.

Corder, S. (1983). Strategies of Communication. In: Færch, C., Kasper G. (eds.), Strategies in Interlanguage Communication. London: Longman, 15-19.

Dörnyei, Z., \& Thurrell, S. (1991). Strategic Competence and How to Teach it. ELT, 45(1), 16-23.

Fujita, K. (2009). A Prospect for Evolutionary Adequacy: Merge and the Evolution and Development of Human Language. Biolinguistics, 3(2), 128-153.

Gass, S., \& Varonis, E. (1984). The Effect of Familiarity on the Comprehensibility of Nonnative Speech. Language Learning, 34(1), 65-89.

Gimadeeva, A.A., Garifullina, D.B., \& Garaeva, M.R. (2019). Lexical-semantic Aspect of the Concept "Fear" (on the Material of the English and Tatar Phraseological Units with the Component-zoonim). Kazan Linguistic Journal, 2(1), 11-18.

Gizyatova, L.A. (2018). Socio-cultural Aspect of Foreign Language Teaching. Kazan Linguistic Journal, 1(2(1)), 94-99.

Greenfield, P.M. (1991). Language, Tools and Brain: The Ontogeny and Phylogeny of Hierarchically Organized Sequential Behavior. Behavioral and Brain Sciences, 14, 531595.

Greenfield, P.M. (1998). Language, Tools, and Brain Revisited. Behavioral and Brain Sciences, 21(1), 159-163.

Issers, O. S. (2008). Communicative Strategies and Tactics of Russian Speech. Mocow. Published by LKI, $288 \mathrm{p}$.

Kolesov, V.V. (2002). Philosophy of a Russian Word. St. Petersburg. UNA, 448 p.

Kondrateva, O. N. (2007). Soul, Heart, Mind. Anthropology of Concepts. Moscow. pp. 80-92.

Lafford, B. (2004). The Effect of the Context of Learning on the Use of Communication Strategies by Learners of Spanish as a Second Language. Studies in Second Language Acquisition, $26,201-225$.

Marantz, A. (2005). Generative Linguistics Within the Cognitive Neuroscience of Language. The Linguistic Review, 22, 429-445.

Mieder, W. (2008). English Proverbs. Stuttgart: Philipp Reclam, 152 p.

Mokienko, V.M., Ermolaeva, Yu.A., \& Zainuldinov, A.A. (2008). Dictionary of Russian Proverbs. Moscow. Astrel, $381 \mathrm{p}$.

Murrey, Yu.V. (2008). Russian Proverbs, Sayings and Idioms and their English Equivalents. Moscow, ACT, St. Petersburg. Sova, 384 p.

Nikonova, Zh.V. (2009). Frame Analysis of Speech Acts (A Case Study of Contemporary German). Nizhniy Novgorod, $49 \mathrm{p}$.

Poeppel, D. (2012). The maps problem and the mapping problem: Two challenges for a cognitive neuroscience of speech and language. Cognitive Neuropsychology, 29(1-2), 34-55.

Poeppel, D., \& Embick, D. (2005). Defining the relation between linguistics and neuroscience. In: Cutler, A. (ed.), Twenty-first century psycholinguistics: Four cornerstones. Hillside, NJ: Lawrence Erlbaum. 103-120.

Savenkova, L.B. (2002). Russian Paremiology: Semantic, Linguistic and Cultural Aspects. Rostov-on-Don. Published by Rostov University, 240 p. 
Semenko, N.N. (2010). Cognitive Integration in a Verbalized Frame Space (A Case Study of Russian Paremias). Vestnik of Moscow State Regional University, 1, 47-51.

Simrock, K. (2015). Deutsch Sprichwörter. Philipp Reclam jung.Gmbh\&Co.KG, Stuttgard, p. 183.

Snigerev, I. M. (2010). Russian Folk Proverbs and Parables. Moscow. Axmo, 576 p.

Teliya, V.N. (1986). The Connotative Aspect of the Semantics of Nominative Units. Miscow. Nauka, 143 p.

Tomasello, M. (ed.). (1998). The New Psychology of Language: Cognitive and Functional Approaches to Language Structure. Mahwah, New Jersey \& London: Lawrence Erlbaum, pp. xxiii+292.

Vezhbitskaya, A. (2001). Understanding of Culture by Means of Key Words. Moscow, 288 p.

Zangieva, Z. N. (2014). Proverbs and Sayings Which Characterize Intellectual Abilities of a Man in the Russian, Chechen and Ossetian Languages. Linguistics. Literary Criticism. Study of Folklore. Izvestiya SOIGSI, 33(72). pp.113-122. 